\title{
Heuristics and the Performance of Financial Institutions in South Sudan
}

\author{
Adire Simon Deng*, Lucy Rono, Jane Sang \\ Department of Accounting \& Finance, Moi University, Kesses, Kenya \\ Email: ${ }^{\star}$ geologistcamp@aol.com
}

How to cite this paper: Deng, A. S., Rono, L., \& Sang, J. (2020). Heuristics and the Performance of Financial Institutions in South Sudan. Modern Economy, 11, 1641-1651. https://doi.org/10.4236/me.2020.1110114

Received: August 14, 2020

Accepted: October 27, 2020

Published: October 30, 2020

Copyright (C 2020 by author(s) and Scientific Research Publishing Inc. This work is licensed under the Creative Commons Attribution International License (CC BY 4.0).

http://creativecommons.org/licenses/by/4.0/

\begin{abstract}
We study the relationship between heuristics and the performance of financial institutions in South Sudan using measures of institutional performance and heuristics. Using the ARDL model, we establish that heuristics indicators such as anchoring, availability, and halo effect negatively and significantly affect the performance of financial institutions while disaster neglect and overconfidence seem not to significantly exactly influence the performance of financial institutions in South Sudan. On the other hand, confirmation seems to significantly affect the performance of financial institutions in the country.
\end{abstract}

\section{Keywords}

Heuristics, Financial Institutions, Institutional Performance, South Sudan

\section{Introduction}

Performance is the driving force of every organization and organizations strive to achieve excellence in performance in all areas of operation while according to Yalcin et al. (2016), heuristics are the shortcuts and rule of thumb caused by data processing errors. Adesugba and Bambale (2016) argue that the objective of measuring performance does not only cover how a business is performing but also gives an insight on how business can perform better. Organizational performance is organization's capability to accomplish its goals effectively and efficiently using resources (Daft, 2000). Rezaei et al. (2018) regard organizational performance as the goals and achievement of a given organization. On the other hand, Richardo \& Wade (2001) noted that achievement of organizational goals and objectives is considered organizational performance. Performance is a continuous and flexible process that involves managers and those whom they manage acting as partners within a framework that sets out how they can best work 
together to achieve the required results (Armstrong, 2006; Rosta, 2008). Firm performance is attained in a sequence of events that follow some logical flow starting from acquisition and configuration of resources, developing capabilities, building competences and ultimately leading to superior performance. According to Hernant (2009) performance is a consequence of environmental factors and the extent to which the firm is patronized by consumers, which in turn is a consequence of how well firm attributes like: location, open hours, merchandise, firm layout, service, advertising, correspond to consumers' evaluative criteria for their firm choice behavior. Further, the firm's decision on firm attributes is influenced by underlying factors, such as local competition and local demand characteristics which enhance or diminish the overall performance of the firm.

Performance is the end result of activities and includes the actual outcomes of the organization operational process (Wheelen \& Hunger, 2010). Organizational performance encompasses many specific areas of firm outcomes (Nwokah, 2008). Musah (2008) indicates that organizational performance should be measured through various indicators depending on the organizational structure. In agreement, Kent and Weese (2000) indicated that performance of the organizations is measured by the congruence between the goals of the organization and the observed outcome. Other authors (Richard et al., 2009; Thang et al., 2008; Morgan et al., 2003) argued that organization performance is related to customer satisfaction, employee satisfaction, increase of the productivity, and superior profit for the organization while Rezaei et al. (2018) suggest the use of multiple indicators in the measurement of organizational performance, which includes both financial and non-financial measures. At the same time with the emergence of the resource-based view (RBV) of the firm, the focus of performance shifted from industry to firm specific assets (Spanos \& Lioukas, 2001). Saleem and Khurshid (2014) identified employee motivation in the organization as a measure of organizational performance.

In their study Savaneviciene and Stankeviciute (2010) indicated that whereas profit-oriented organizations tend to measure performance through financial turnover and profitability, non-profit oriented organizations cannot use such measure and thus focus on social benefits to measure performance. In an attempt to determine performance of the firm, empirical literature points that several indicators have been identified as measures of performance to include productivity, quality, innovation, profitability, creativity, commitment, loyalty, decision making, participation, effectiveness, efficiency and effort. In addition to these indicators, Rodwell and Teo (2004) pointed out that alongside customer loyalty, customer base is also a measure of firm performance.

Organizational performance has been measured using a three-item scale: return on assets, sales growth and increase in market share. Available literature shows the use of these indicators to measure changes in knowledge, competencies and learning of organizations. Shrader (2001) and Stuart (2000), among others, have adopted sales growth; Goerzen \& Beamish (2005), return on assets 
and Dussauge, Garrette and Mitchell (2004), increase in market share. Firm performance is measured in terms of sales level, profitability, productivity and customer base level.

The efficient market hypothesis assumes that markets are rational (Yalcin et al., 2016). However, a stream of researchers exhibits many observed anomalies that are not explained by the arguments of the efficient market hypothesis Heuristics are quite functional to alleviate the cognitive efforts for making the decision process easier which may otherwise require too much time and mental resources. On the other hand, heuristics sometimes cause inevitable biases.

In making credit decisions, financial institutions' credit personnel are guided by objective (collateral) and subjective (know your customer) considerations. Human beings are referred to as making decisions on the basis of their experience and intuition, instead of gathering information, which would encourage them to make better decisions (Shah et al., 2018). Baker and Nofsinger (2010) observe that investment decision making process is affected by psychological biases, fundamental heuristics and cognitive errors. The study will investigate the effect of these biases on the relationship between heuristics and performance of financial institutions in South Sudan.

\section{Literature}

It is a given among economists that a healthy financial system is a key underpinning of a healthy economy (Pakravan, 2014). Banks are integral to economic development through the financial services they provide. Their intermediation role can be said to be a catalyst for economic growth. The efficient and effective performance of the banking industry over time is an index of financial stability in any nation. The extent to which a bank extends credit to the public for productive activities accelerates the pace of a nation's economic growth and its long-term sustainability (Kolapo, Ayeni, \& Oke, 2012). Performance of financial institutions is represented mainly by quantifiable financial indicators. The literature on the determinants of bank performance has closely tied same with profitability measures such as ROA, and ROE (Bougatef, 2017; Chirwa, 2003; Majumder \& Li, 2018). Profitability accounts for the impact of better financial soundness on bank risk bearing capacity and, on their ability, to perform liquidity transformation. According to Popa et al. (2009), popular measures of bank performances are return on assets (ROA), return on equity (ROE), net banking income and the efficiency ratio.

On the other front, different researchers assessed performance in terms of bank prices (as measured by interest rates) rather than bank profitability. The justification as explained by Chirwa (2003) is that the use of price-concentration relationship instead of profit concentration relationship measures the performance of banks and their market structure. They argued that the price-concentration relationship imply that high levels of concentration allow for non-competitive behavior that would result in lower interest rates given to depositors and/or higher 
lending rates to borrowers. However, Chirwa (2003) also showed that price measures of performance create problems of cross subsidization of multiproduct firm.

The bank performance measure can be divided into traditional measures and market-based measures (Aktan \& Bulut, 2008). The most common measure of bank performance is profitability. Profitability is measured using the following criteria: Return on Assets = a net profit/total asset shows the ability of management to acquire deposits at a reasonable cost and invest them in profitable investments (Ahmed, 2009). This ratio indicates how much net income is generated per $£$ of assets. The higher the ROA, the more the profitable the bank is. Return on Equity $(\mathrm{ROE})=$ net profit/total equity. $\mathrm{ROE}$ is the most important indicator of a bank's profitability and growth potential. It is the rate of return to shareholders or the percentage return on each $\mathfrak{E}$ of equity invested in the bank. Liquidity indicates the ability of the bank to meet its financial obligations in a timely and effective manner. Financial liabilities are attracted through retail and wholesale distribution channels. Retail generated funding is considered less interest elastic and more reliable than deposits attracted from wholesale distribution channels (Thygerson, 1995). The following ratios are used to measure liquidity: Liquid Assets to Deposit-Borrowing Ratio (LADST) = liquid asset/customer deposit and short term borrowed funds. This ratio indicates the percentage of short-term obligations that could be met with the bank's liquid assets in the case of sudden withdrawals. Net Loans to Total Asset ratio (NLTA) $=$ Net Loans/Total Assets NLTA measures the percentage of assets that is tied up in loans. The higher the ratio, the less liquid the bank is. Net Loans to Deposit and borrowing $(\mathrm{NLDST})=$ Net loans/total deposits and short-term borrowings. This ratio indicates the percentage of the total deposits locked into non-liquid assets. A high figure denotes lower liquidity.

A moderator variable is one which systematically modifies either the form andlor strength of the relationship between a predictor and a criterion variable (Sharma et al., 1981). Moderating effects are also referred to as interaction and conditioning effects. A moderator variable may reduce or enhance the direction of the relationship between a predictor variable and a dependent variable, or it may even change the direction of the relationship between the two variables from positive to negative or vice versa (Lindley \& Walker, 1993).

The efficient market hypothesis assumes that markets are rational (Yalcin et al., 2016). However, a stream of researchers exhibits many observed market movements so called anomalies that are not explained by the arguments of the efficient market hypothesis. Gigerenzer and Gaissmaier (2011) define heuristic as a strategy that ignores part of the information, with the goal of making decisions more quickly, frugally, and/or accurately than more complex methods. According to Yalcin et al. (2016), heuristics are the shortcuts and rule of thumb caused by data processing errors. They are quite functional to alleviate the cognitive efforts for making the decision process easier which may otherwise require 
too much time and mental resources. On the other hand, heuristics sometimes cause inevitable biases. In making credit decisions, financial institutions' credit personnel are guided by objective (collateral) and subjective (know your customer) considerations. Human beings are referred to as making decisions on the basis of their experience and intuition, instead of gathering information, which would encourage them to make better decisions (Shah et al., 2018). Kahneman, Lovallo and Sibony (2011) pointed out that the most common heuristics and cognitive biases in decision making included confirmation bias, availability bias, anchoring, halo effect, overconfidence, disaster neglect and loss aversion. Baker and Nofsinger (2010) observe that investment decision making process is affected by psychological biases, fundamental heuristics and cognitive errors. The study will investigate the effect of these biases on the relationship between credit risk and performance of financial institutions in South Sudan.

Heuristics has been ably documented as affecting decisions (Gitau et al., 2018) and Kahneman \& Tversky (1979) ably brought out the common heuristic and cognitive biases in managerial decision making which ends up lowering the quality of decisions made. McKinsey (2010) studied one thousand major business investments and concluded that when business spend time in trying to remove biases in their decision-making process, their return increased by seven points. Palmaer and Linden (2015) using a case study of private advisors' decision-making behaviour in a Swedish Bank concluded that it was evident that heuristics and intuition played important parts in the advisors' decision-making process, and that the reliance on technology varied between the advisors.

\section{Methodology}

We used the the ARDL model and consider other data properties using various tests outlined in the subsections.

\subsection{The ARDL Model}

We adopt the ARDL model in studying the relationship between heuristics and performance of financial institutions in South Sudan. This model is an interventional method for time series models that do not clearly feature the elements of simple and standard OLS as well as Error Correction models (ECM). The method also works with series that are of varying integral order $I(0)$ or $I(1)$, but not $I(2)$ and it carries more preferential weight among econometric researchers because different variables assume different lags as they are fitted into the model Pesaran and Shin (1999) and Pesaran et al. The traditional ARDL model can be expressed in the following form:

$$
\begin{aligned}
\Delta Y t= & \alpha 0+\sum \Phi i \Delta y_{t-i}+\sum \beta j \Delta x_{t-j}+\sum \delta k \Delta z_{t-i} \\
& +\theta_{1} y_{t-1}+\theta_{2} x_{t-1}+\theta_{3} z_{t-1}+u t
\end{aligned}
$$

where $\Phi i, \beta$ and $\delta i$ are the short-run coefficients while $\theta_{1}, \theta_{2}$ and $\theta_{3}$ represent the ARDL long-run coefficients and the error-correction term, $z_{t-1}$ is replaced by the $y_{t-1}, x_{t-1}$, and $z_{t-1}$ terms. Lagged residuals series therefore be- 
come $z_{t-1}=\left(y_{t-1}-a_{0}-a_{1} x_{1 t-1}-a_{2} x_{2 t-1}\right)$.

\subsection{Stationarity of the Model}

We used the AR roots model to investigate the stationarity of the model and as shown below, the roots of the characterisitic polymonial lay within the unit circle (Figure 1).

\subsection{Selection of Optimal Lag Structure}

We determine the optimum lag length(k) by using the Akaike Information Criterion (AIC), Schwarz Bayesian Criterion (SBC) or Hannan-Quinn Criterion (HQC) in order to obtain Gaussian error terms that are free from serial correlation and heteroscedasticity. These criteria are based on a high log-likelihood value, with a "penalty" for including more lags to achieve this. As shown below, all the methods have chosen lag 1 to be the optimal lag to use (Table 1).

\subsection{Model Diagnostics: Serial Correlation}

After estimating our appropriate model equation using the appropriate lag, we carry out model diagnostics by checking for autocorrelation using the Breusch-Godfrey Serial Correlation LM Test method under the null hypothesis that there is autocorrelation against of the alternative that errors are either $\mathrm{AR}(\mathrm{m})$ or $\mathrm{MA}(\mathrm{m})$, form $=1,2,3, \cdots$, etc. (Table 2). This is a key element in the assumptions of the ARDL/Bounds Testing methodology of Pesaran et al. (2001). As presented, the $\mathrm{P}$-value associated with the Chi-square statistic is way above $5 \%$ hence we cannot reject the null hypothesis that errors are serially independent.

\section{Inverse Roots of AR Characteristic Polynomial}

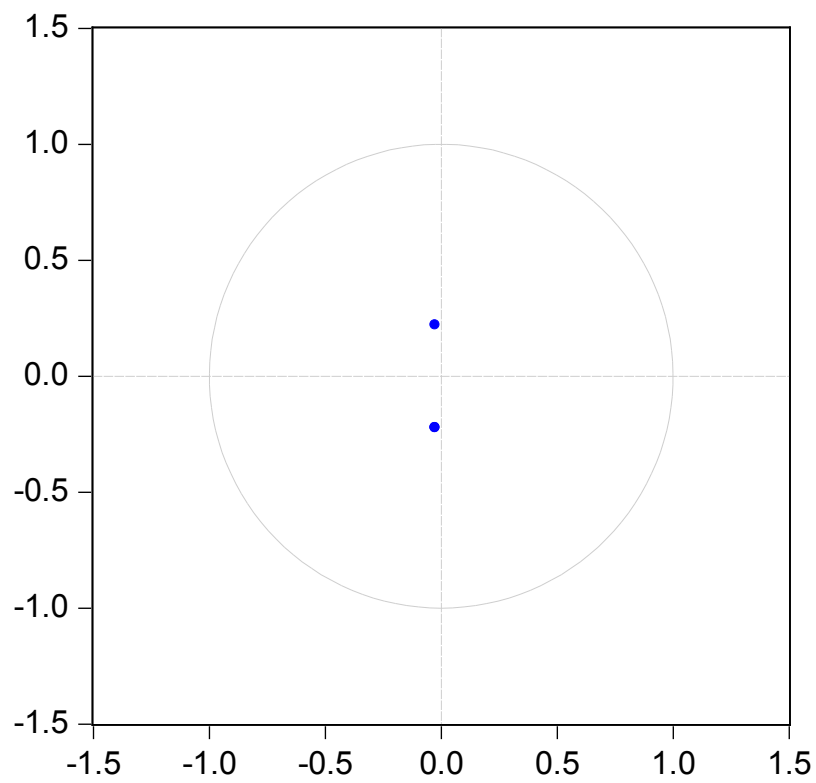

Figure 1. Inverse roots of the characteristic polynomial. Source: Author's illustrations. 
Table 1. Lag structure.

\begin{tabular}{ccccccc}
\hline Lag & LogL & LR & FPE & AIC & SC & HQ \\
\hline 0 & -16.18600 & NA & $0.120662^{\star}$ & $0.721970^{*}$ & $0.985217^{*}$ & $0.826138^{*}$ \\
1 & -16.11865 & 0.116613 & 0.124129 & 0.749810 & 1.045963 & 0.866999 \\
2 & -16.04660 & 0.122592 & 0.127694 & 0.777510 & 1.106569 & 0.907720 \\
3 & -14.82451 & 2.042895 & 0.126946 & 0.770881 & 1.132845 & 0.914111 \\
4 & -14.68115 & 0.235366 & 0.130352 & 0.796452 & 1.191322 & 0.952703 \\
5 & -12.23731 & $3.939315^{\star}$ & 0.124987 & 0.753353 & 1.181129 & 0.922625 \\
6 & -12.22430 & 0.020595 & 0.128887 & 0.782815 & 1.243497 & 0.965108 \\
7 & -10.73194 & 2.316498 & 0.127194 & 0.768117 & 1.261705 & 0.963431 \\
\hline
\end{tabular}

Source: Author's calculations. ${ }^{*}$ indicates lag order selected by the criterion; LR: sequential modified LR test statistic (each test at 5\% level); FPE: Final prediction error; AIC: Akaike information criterion; SC: Schwarz information criterion; HQ: Hannan-Quinn information criterion.

Table 2. Breusch-godfrey serial correlation LM test.

\begin{tabular}{cccc}
\hline F-statistic & 1.486520 & Prob. F (2,41) & 0.2381 \\
Obs $^{*}$ R-squared & 4.732735 & Prob. Chi-Square (2) & 0.0938 \\
\hline
\end{tabular}

Source: Author's calculations.

\subsection{Model Diagnostics: Dynamic Stability}

We employ the Recursive OLS Estimates-CUSUM Test to determine model stability. The CUSUM (cumulative sum) statistics are defined according to:

$$
\operatorname{CUSUM}_{t}=\sum_{i=k}^{t} W_{i+1, i}
$$

for $t=k, k+1, \cdots, T-1$, where $k=2 p+s+1$ is the minimum sample size for which we can fit the model. Under the null hypothesis, the CUSUM $_{t}$ statistic is drawn from a $\operatorname{CUSUM}_{(t-k)}$ distribution. The $\operatorname{CUSUM}_{(t-k)}$ distribution is a symmetric distribution centered at 0 . Its dispersion increases as $t-k$ increases. We reject the null hypothesis at the $5 \%$ significance level if CUSUM $_{t}$ is below the 2.5-percentile or above the 97.5-percentile of the $\operatorname{CUSUM}_{(t-k)}$ distribution.

In our study (Figure 2), model stability was carried using Recursive OLS Estimates-CUSUM Test and our results indicates that the trend line lies within the boundaries as shown above. As observed the trend line for the CUSUM test observes a positive bounds projection that is within the $5 \%$ level of significance.

\section{Results}

The table below presents the results obtained from the estimation of the model presented in 3.1 .

From the results, we observe that anchoring, availability and halo effect negatively and significantly affect on the performance of finance insituttions in South Sudan. However, disaster neglect and overconfidence do not significantly influence the performance of financial insitutions. On the other hand, confirmation seems to significantly exact a positve impact. These results bear signifcant relev- 
ance to the litaerature. These findings are the result of the pioneer work on the performance of financial instutions in South Sudan considering the issues of heuristics. They provide guiding ground for policy in the banking sector.

\section{Conclusion}

This study was conducted to analyze the relationship between heuristics and the performance of financial institutions in South Sudan. Measures of institutional performance, such as financial institution profitability, return on equity, return on assets, net interest margin, net income and efficiency ratio were adopted. On the other hand, heuristics was measured using anchoring, availability, confirmation, disaster neglect, halo effect and over confidence. An ARDL model was used to examine the relationship (Table 3). Our results show that anchoring, availability and halo effect negatively and significantly affect the performance of finance institutions while disaster neglect and overconfidence seem not to significantly exactly influence the performance of financial institutions in South Sudan. On the other hand, confirmation seems to significantly affect the performance of

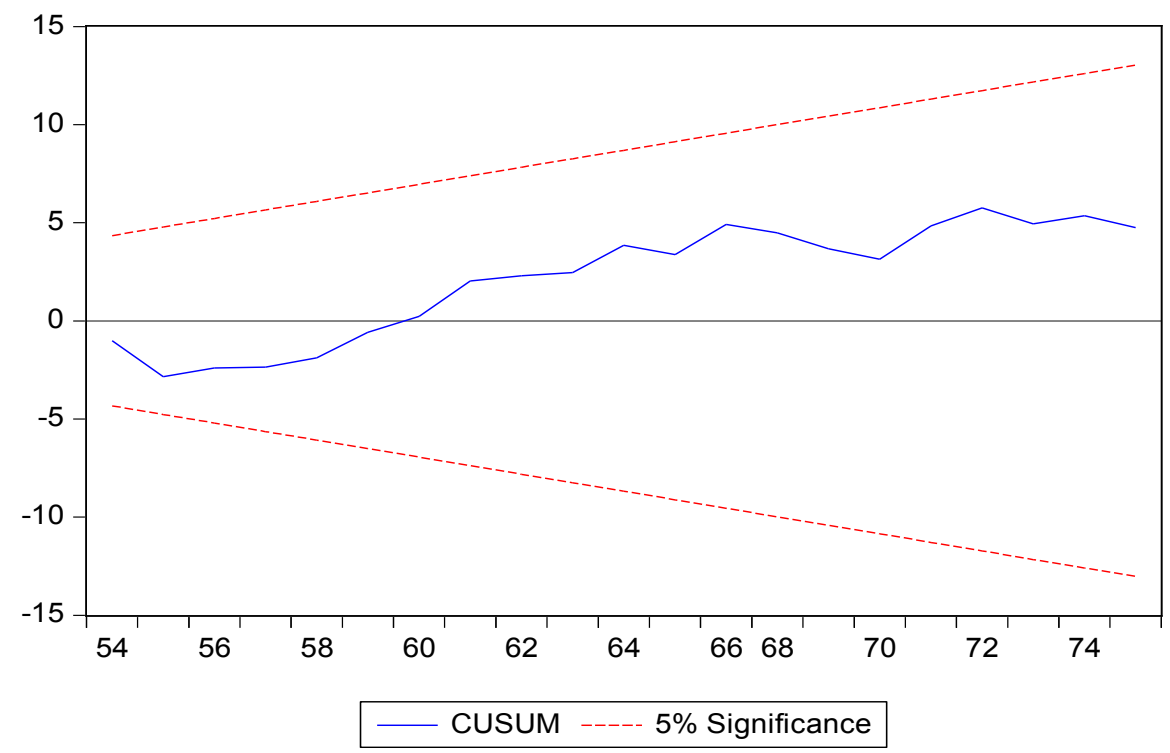

Figure 2. Bounds for the dynamic stability of the model. Source: Author's illustrations.

Table 3. ARDL estimation.

\begin{tabular}{ccccc}
\hline Variable & Coefficient & Std. Error & t-Statistic & Prob. $^{*}$ \\
\hline ANCHORING & -0.308957 & 0.139260 & -2.218557 & 0.0318 \\
AVAILABILITY & -0.306322 & 0.106053 & -2.888390 & 0.0060 \\
CONFIRMATION & 0.324006 & 0.107544 & 3.012783 & 0.0043 \\
DISASTER_NEGLECT & -0.014403 & 0.133660 & -0.107756 & 0.9147 \\
HALO_EFFECT (-2) & -0.594922 & 0.186932 & -3.182558 & 0.0027 \\
OVERCONFIDENCE $(1)$ & -0.165093 & 0.184501 & -0.894806 & 0.3759 \\
C & 0.911397 & 0.232311 & 3.923169 & 0.0003 \\
\hline
\end{tabular}

Source: Author's calculations. 
financial institutions in the country. This study was limited to only heurisitics without regard to other parameters that influence the performance of financial institutions and as such, further research may focus in the direction of credit risk in the same context of institutional performances.

\section{Conflicts of Interest}

The authors declare no conflicts of interest regarding the publication of this paper.

\section{References}

Adesugba, A. K., \& Bambale, A. J. (2016). The Effects of Credit Risk Management on the Performance of Some Selected Deposit Money Banks in Nigeria. International Journal of Management and Commerce Innovations, 4, 73-83.

Aktan, B., \& Bulut, C. (2008). Financial Performance Impacts of Corporate Entrepreneurship in Emerging Markets: A Case Study of Turkey. European Journal of Economics, Finance and Administrative Science, 12, 69-79.

Ali Ahmed, H. J. (2009). Managerial Ownership Concentration and Agency Conflict Using Logistic Regression Approach: Evidence from Bursa Malaysia. Journal of Management Research, 1, 1-10. https://doi.org/10.5296/jmr.v1i1.36

Armstrong, M. (2006). A Handbook of Human Resource Management Practice (10th ed.). Cambridge: Cambridge University Press.

Baker, H. K., \& Nofsinger, J. R. (2010). Behavioral Finance: An Overview. In Behavioral Finance: Investors, Corporations, and Markets (pp. 1-21). Hoboken, NJ: Wiley. https://doi.org/10.1002/9781118258415.ch1

Bougatef, K. (2017). Determinants of Bank Profitability in Tunisia: Does Corruption Matter? Journal of Money Laundering Control, 20, 70-78.

Chirwa, E. W. (2003). Determinants of Commercial Banks' Profitability in Malawi: A Co-Integration Approach. Applied Financial Economics, 13, 565-571. https://doi.org/10.1080/0960310022000020933

Daft, R. L. (2000). Organization Theory and Design (7th ed.). Cincinnati OH: South-Western College Publishing.

Dussauge, P., Garrette, B., \& Mitchell, W. (2000). Learning from Competing Partners: Outcomes and Durations of Scale and Link Alliances in Europe, North America and Asia. Strategic Management Journal, 21, 99-126. https://doi.org/10.1002/(SICI)1097-0266(200002)21:2<99::AID-SMJ80>3.0.CO;2-G

Gigerenzer, G., \& Gaissmaier, W. (2011). Heuristic Decision Making. The Annual Review of Psychology, 62, 451-482. https://doi.org/10.1146/annurev-psych-120709-145346

Gitau, G. G., Kiragu, D. N., \& Kamau, R. (2018). Effect of Heuristic Factors and Real Estate Investment in Embu County, Kenya. International Journal of Academic Research in Accounting, Finance and Management Sciences, 8, 30-38. https://doi.org/10.6007/IJARAFMS/v8-i4/5183

Goerzen, A., \& Beamish, P. W. (2005). The Effect of Alliance Network Diversity on Multinational Enterprise Performance. Strategic Management Journal, 26, 333-354.

Hernant, M. (2009). Profitability Performance of Supermarkets. The Effects of Scale of Operation, Local Market Conditions, and Conduct on the Economic Performance of Supermarkets. Dissertation for the Degree of Doctor of Philosophy, Ph.D. Stockholm School of Economics. 
Kahneman, D., \& Tversky, A. (1979). Prospect Theory: An Analysis of Decision under Risk. Econometrica, 47, 263-292. https://doi.org/10.2307/1914185

Kent, A., \& Weese, W. J. (2000). Do Effective Organizations Have Better Executive Leadership and/or Organizational Cultures? A Study of Selected Sport Organizations in Canada. European Journal for Sport Management, 7, 4-21.

Kolapo, T. F., Ayeni, R. K., \& Oke, M. O. (2012). Credit Risk and Commercial Banks' Performance in Nigeria: A Panel Model Approach. Australian Journal of Business and Management Research, 2, 31-38.

Lindley, P., \& Walker, S. N. (1993). Theoretical and Methodological Differentiation of Moderation and Mediation. Nursing Research, 42, 276-279.

Lovallo, D., \& Sibony, O. (2011). Before You Make that Big Decision. Harvard Business Review, 89, 50-60, 137.

Majumder, T. H., \& Li, X. (2018). Bank Risk and Performance in an Emerging Market Setting: The Case of Bangladesh. Journal of Economics, Finance and Administrative Science, 23, 199-229. https://doi.org/10.1108/JEFAS-07-2017-0084

McKinsey, V., \& Zawada, C. C. (2010). Do You Have a Long-Term Pricing Strategy? McKinsey Quarterly, 1-7.

Morgan, N. A., Vorhies, D. W., \& Mason, C. (2003). Market Orientation, Marketing Capabilities, and Firm Performance. Strategic Management Journal, 30, 909-920.

Musah, S. (2008). Evaluating The Extent to Which People and Performance AMO Model Has Contributed to the Strategic Human Resource Debate. Journal of Management, 15, 67-79.

Nwokah, N. G. (2008). Strategic Market Orientation and Business Performance the Study of Food and Beverages Organizations in Nigeria. European Journal of Marketing, 42, 279-289. https://doi.org/10.1108/03090560810852922

Pakravan, K. (2014). Bank Capital: The Case against Basel. Journal of Financial Regulation and Compliance, 22, 208-218. https://doi.org/10.1108/JFRC-09-2013-0030

Palmaer, Y., \& Linden, N. (2015). Managing Risk and Uncertainty in the Mortgage Loan Process-A Case Study of Private Advisors' Decision-Making Behaviour in a Swedish Bank. Unpublished Thesis, Uppsala: Uppsala University.

Popa, G., Mihallescu, L., \&Caragea, C. (2009). EVA-Advanced Method for Performance Evaluation in Banks. Economia Seria Management Journal, 12, 168-173.

Rezaei, G., Mardani, A., Senin A. A., Wong, K. Y., Sadeghi, L., Najmi, M., \& Shaharoun, A. M. (2018). Relationship between Culture of Excellence and Organisational Performance in Iranian Manufacturing Companies. Total Quality Management \& Business Excellence, 29, 94-115. https://doi.org/10.1080/14783363.2016.1168692

Ricardo, R., \& Wade, D. (2001). Corporate Performance Management: How to Build a Better Organization through Measurement Driven Strategies Alignment. Oxford: Butterworth-Heinemann.

Richard, P. J., Devinney, T. M., Yip, G. S., \& Johnson, G. (2009). Measuring Organizational Performance: Towards Methodological Best Practice. Journal of Management, 35, 718-804.

Rodwell, J., \& Teo, S. T. T. (2004). Strategic HRM in For-Profit and Non-Profit Organizations in a Knowledge-Intensive Industry. Public Management Review, 6, 311-331.

https://doi.org/10.1080/1471903042000256510

Rosta, J. (2008). Risk Management: Models Built on Good Times Fail in Bad: Will Going Back to Basics and Empowering CROs Fix the Problem? (Front and Center). American Banker, 118, No. 12. 
Saleem, I., \& Khurshid, A. (2014). Do Human Resource Practices Affect Employee Performance? Pakistan Business Review, 15, 669-688.

Savaneviciene, A., \& Stankeviciute, Z. (2010). The Models Exploring the "Black Box" between HRM and Organizational Performance. Engineering Economics, 21, 426-434.

Shah, S. Z. A., Ahmad, M., \& Mahmood, F. (2018). Heuristic Biases in Investment Decision-Making and Perceived Market Efficiency: A Survey at the Pakistan Stock Exchange. Qualitative Research in Financial Markets, 10, 85-110. https://doi.org/10.1108/QRFM-04-2017-0033

Shrader, C. (2001). Collaboration and Performance in Foreign Markets, the Case of Young High Technology Manufacturing Firms. Academy of Management Journal, 44, 45-60.

Spanos, Y., \& Lioukas, S. (2001). An Examination into the Causal Logic of Rent Generation: Contrasting Porter's Competitive Strategy Framework and the Resource-Based Perspective. Strategic Management Journal, 22, 907-934.

https://doi.org/10.1002/smj.174

Stuart, T. E. (2000). Interorganizational Alliances and the Performance of Firms, a Study of Growth and Innovation Rates in a High-Technology Industry. Strategic Management Journal, 21, 791-811.

Thang, N. N. et al. (2008). The Impact of Training on Firm Performance: The Case of Vietnam. 7th International Conference of the Academy of Human Resource Development (Asia Chapter), 3-6 November, Bangkok, Thailand.

Thygerson, K. J. (1995). Management of Financial Institutions (1st Edition). Harpercollins College Div.

Wheelen, T. L., \& Hunger, J. D. (2010). Concepts in Strategic Management \& Business Policy. London: Prentice Hall.

Yalcin, K. C., Tatoglu, E., \& Zai, S. (2016). Developing an Instrument for Measuring the Effects of Heuristics on Investment Decisions. Kybernetes, 45, 1052-1071.

https://doi.org/10.1108/K-05-2015-0130 